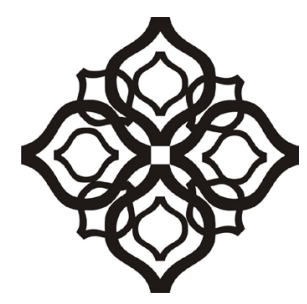

Shirkah

Journal of Economics and Business 


\section{Shirkah}

Journal of Economics and Business

Vol. 4, No. 2, May-August 2019

ISSN: 2503-4235 (p); 2503-4243 (e)

\section{Editor in Chief}

Fitri Wulandari

\section{Managing Editor}

Jasanta Peranginangin

\section{Editorial Boards}

AAbdul Azim Islahi,

Islamic Economics Institute, King Abdulaziz University, Saudi Arabia

Abu Umar Faruq Ahmad,

UBD School of Business and Economics Universiti, Brunei Darussalam

Cedomir Nestorovic,

ESSEC Business School Asia Pacific, Singapore

Johan Fischer,

Department of Social Sciences and Business Roskilde Universitetscenter, Denmark Muhamed Zulkhibri,

Islamic Research and Training Institute, Islamic Development Bank, Saudi Arabia M. Kabir Hassan,

Department of Economics and Finance, University of New Orleans, United States Musa Asy'arie,

Faculty of Islamic Economics and Business, IAIN Surakarta, Indonesia

Nunung Nurul Hidayah,

Aston Business School, Aston University, Birmingham, United Kingdom

Saim Kayadibi,

Department of Economics, Kulliyyah of Economics and Management Science,

International Islamic University Malaysia, Malaysia

Shaikh M Ghazanfar,

Departement of Economics, University of Idaho, Russian Federation 
Sigit S. Wibowo,

Department of Management, Faculty of Economics and Business, Universitas Indonesia, Indonesia

Vihang R. Errunza,

Desmarais Global Finance Research Centre, Desautels Faculty and Management, McGill University, Canada

\section{Assistant to Editor}

M. Endy Saputro

M. Zainal Anwar

Shirkah Journal of Economics and Business is a peer-reviewed journal published three times a year (January-April, May-August and September-December) by Faculty of Islamic Economics and Business, Institut Agama Islam Negeri (IAIN) Surakarta Central Java, Indonesia. The main objective of Shirkah is to offer an academic space of exchange ideas and initiate the increase number of qualified article produced by postgraduate students, practitioners and academicians.

\section{Editorial Office}

Ruang Jurnal Shirkah

Lantai Dasar, Sayap Barat, Fakultas Ekonomi dan Bisnis Islam, IAIN Surakarta

Jln. Pandawa No. 1, Kartasura, Sukoharjo, Jawa Tengah Kode Pos. 57168

Phone (+62271) 781516 Fax: (+62271)782336

E-mail: shirkahjournal@iainsurakarta.ac.id; shirkahiainsurakarta@gmail.com Website: http://shirkah.or.id/ 


\section{Shirkah}

Journal of Economics and Business

Vol. 4, No. 2, May-August 2019

ISSN: 2503-4235 (p); 2503-4243 (e)

\section{Table of Contents}

\section{Articles}

Abd Hannan

Santripreneurship and Local Wisdom Economic Creative of Pesantren Miftahul Ulum

Muh. Salahuddin

Nurhilaliati

Zaenal Arifin

Entrepreneurship and Economics of Pesantrens in Lombok Island

Abdul Jalil

Alumni Networks and Economic Reinforcement in Pesantren

Ummussabri

Jehan Maya Zayanie

Ahsana Fitria

Rosidatul Kamariah

Bank Wakaf Mikro and Creative Economics in Pesantren Buntet

Farihatul Qamariyah

Muslim Business Women in Indonesia

Fachrurazi

Dwi Srya Atmaja

Zaenuddin Hudi Prasojo

Muslim Businessmen and Chinese Economics in Singkawang 


\title{
Muslim Businessmen and Chinese Economics in Singkawang
}

\author{
Fachrurazi \\ Institut Agama Islam Negeri (IAIN) Pontianak \\ ferry.7co@gmail.com \\ Dwi Surya Atmaja \\ Institut Agama Islam Negeri (IAIN) Pontianak \\ Atmaja651109@gmail.com \\ Zaenuddin Hudi Prasojo \\ Institut Agama Islam Negeri (IAIN) Pontianak \\ zaestain@yahoo.com
}

\begin{abstract}
Instead of being known as the "City of Tasbih", nowadays Singkawang is either known as the "City of Amoy (Chinese girls)" or the "City of Thousand ChineseTemples". Cap Go Meh annually International Festival is another evidence of Chinese image making towards the city. This indicates a sort of Chinese domination which must be studied, economically, politically, and socially. Furthermore, the research aims to explore the dynamics of Chinese Counterpart especially Muslim Business elites' challenge such ironic the ongoing dominating development. To explore the dynamics, in-depth interviews were held. Key figures among Muslim businessmen, Chinese elites, government officials, even lay people were questioned in order to obtain a clear description and balanced analysis of possible biases and perspectives of the interviewees. Quantitative data are analized and discussed. In short, the research's findings are: The desire of an Islamic Singkawang is still intact, driven mainly by Muslim businessmen, in order to defend the existence and of Muslim in face of their powerlessness amidst the domination of Chinese elites.
\end{abstract}

Keyword: Muslim; businessmen, Chinesse, economics, domination, Singkawang 


\section{Introduction}

The Chinese came to Indonesia, particularly the northern coasts of West Kalimantan in order to find their fortune. Their initial arrival was under the blessings of Sambas Sultanate as workers working several gold mines. The factors pushing the Chinese to migrate into West Kalimantan were, among others, difficult economic conditions, population pressure, and political upheavals, causing difficulties in finding work in their homeland. "Nanyang", meaning, "the Southern Seas", were viewed as a land of hope by these Chinese, who attempted to migrate there, in hopes of building a good life and finding pleasure. The northern coast of West Kalimantan is one of the areas included in this image of Nanyang. Over time, after several migration waves, several Chinese settlements emerged in this area, most emerging around gold mining sites, such as Samalantan and Monterado. The Chinese there also undergoes acculturation with locals, particularly Dayaks, so that some of them ended up as farmers, traders, and then founders of trading kongsis.

Since their arrival, the Chinese tended to gravitate to economic ventures, making them a reliable group of immigrants to the Dutch East Indies government. Their economic activities started to dominate the distribution and trade of agricultural products, such as: vegetables, secondary crops, rubber, pepper, copra, and other produces. Their trade networks were not limited only to the trade networks of Sambas Sultanate, but it had reached several areas of Southeast Asia, particularly Singapore. The Chinese remained consistent in their economic activities. Their economic efforts became smoother and more expansive. They also generally were not too impressed or involved with political and national matters, even though Indonesia was undergoing its revolution at the time.

This Chinese success in economic matters were then realized by locals, who particularly realized their inferiority in the fields of production, 
distribution and trade networks, and banking. This realization is especially felt by Muslim businessman, who mainly hailed from the Malay ethnicity, when some of them started to build large-scale economic networks, realizing their limited experience in owning international-scale business networks. In contrast, the Chinese businessmen managed to quickly seize trade routes, due to their close connections with businessmen in Hong Kong and Singapore. This is exarcebated by the Chinese socio-economic perspective, which is adamant on obtaining as much profit as possible, no matter what—something that is difficult, even forbidden for Muslim businessmen.

The Chinese skills and consistency in economics and trade should be acknowledged as resilient, surviving from the era of Dutch East Indies, early independence, Old Order, until the New Order. They always try to survive in the economic field, even when facing conflicts with local ethnicities, leading to the Republic of Indonesia's government's political decision (Peraturan Pemerintah Republik Indonesia Number 10, 1959) to force the Chinese to move from villages to cities, particularly Singkawang. This policy instead strengthened the Chinese' spirit and existence. This social capital then strengthened their economic existence, which then becomes centered on Singkawang, which they control economically. Like water which always finds a gap to flow, the trading and distribution works in the villages, left vacant after the Chinese departure, finally falls back under their control, because the locals already developed an economic dependence on the Chinese.

Now, the "mind's eye", of the locals, particularly the Malays (referred from now on as "Muslim businessmen" in this article), is opened. Better late than never, these Muslim businessmen seem to realize that they've been lagging, and they started to awaken and fight the Chinese economic glory. This is exarcebated with the fact that more and more Chinese businesses 
grow, all with very little involvement of Muslim businessmen or none. All of this slowly exarcebates the competition between Muslim and Chinese businessmen.

In accordance to the research goal to describe the dynamics of ethnic interaction between Chinese, Dayaks, and Malays in relation with the plurality and multiculturalism in Singkawang, the researcher uses the qualitative approach. The use of this approach is based on these considerations: (1) the dynamic character of qualitative research fits the intertwined dynamics of social theory and reality. Here, the flexible interrelation between hypothesis, antithesis, and synthesis is urgently needed. The analysis is done in tandem with the data collection; (2) qualitative approach is also needed to investigate deep and wide, thus the strict limits of a quantitative approach's variables is more hindrance than help; (3) another objective is to uncover natural and grounded events; and (4) the investigated aspects can be studied deeper, more holistically, more in detail, and more private.

This research is done in Singkawang, West Kalimantan. This research is in no way directed by racism or dichotomization of ethnic existence, but purely by class existence and struggle analysis. The choice of this setting is done based on the fact that the area is quite unique and challenging to be viewed with the lense of plurality, based on the context of so-called multicultural interaction between Chinese, Dayaks, and Malays. Unique here means as different from other regions, because the Chinese manages to inject their own Chinese colors into the city, as proven by the moniker, "City of Thousand Kelentengs" or "City of Amois", or, as time passes, "a portion of Hong Kong in West Kalimantan."

The subject of this research is the economic dominance of the Chinese, which inherently inspires opposition from local ethnicities, the Malays as Muslims in Singkawang. The data in this research is collected 
using interviews, observations, and document studies. The data is then analyzed with Miles and Huberman's interactive data analysis technique model (1992), which is: data reduction, data display and verification, and conclusion. To ensure data validity, the data is checked using triangulation and member check.

\section{The Contestation}

Many acknowledges the Chinese economic dominance in Singkawang, but quite a few also interpret it rather differently. This Chinese dominance can be viewed as resulting from "negligence" of the locals, particularly Muslim businessmen who seemed rather negligent in maintaining their social class. The "romanticism" of living as locals with abundant "living space" dazzled them, leaving only a few of them able to read and act on opportunities, as well as developing it so that they can continue their business until now. On the other hand, Chinese businessmen seem to be even more focused in building their "throne" of capitalism, using all the resources and potential available in Singkawang as optimally as possible.

Thus, nowadays the Chinese businessmen managed to present themselves as the winners, placing them as the elites of Singkawang. This not just due to their economic successes, but also due to the political success they obtained through it. This is also helped by the image they have built for Singkawang, building an impression of Singkawang as a Chinese city. This all happened due to the Chinese managing to grow and develop as the elite dominating Singkawang, even if there are still some Chinese there living in economic hardships. Generally, both the economic and political fates of Singkawang are in the hands of the Chinese elite. This also shows that the social condition in Singkawang have inverted, from Malay/Muslim control to Chinese control. 
The modern climate of capitalism and modernization is filled with competition in all aspects of life, particularly in economics. The context of this article is specifically about the competition between Muslim and Chinese businessmen. However, this economic competition cannot be separated from religious and cultural perspectives, as well as political power. Thus, both Muslim and Chinese businessmen's successes cannot be separated from those aspects serving as the roots of their respective identities. The spirit of economic success among Chinese businessmen cannot be separated from all forms of their religious and cultural identities, just as the successes of Muslim businessmen cannot be separated from the source of Islamic teachings as the basis of their beliefs, Al-Quran and Hadits. Religion as the spirit in obtaining worldly success reminds one of Weber's great work about, "Protestant ethics" and his critiques and worries about how, "modernization would only make the citizens need bureaucracies, justice, legalities, and administration, but all of those would in turn control us instead" (Weber, 1904: 18).

Weber proposed his ideas, like Calvinism campaigned for asceticism, to stress that the gathering of wealth is in order to obtain more of God's blessings, rather than worldly opulence; the accumulation of capital being the factor enabling a transition from feudalism to capitalism. Nowadays, this logic of chasing wealth for God backfires; religion was what helped the birth of capitalism, while capitalism itself starts to destroy religion quickly (Beilharz, 2003: 366).

These critiques and worries of Weber also remind one of the cruel implications of capitalism, alongside other factual worries, especially by those struggling to prevail in a competition. This also matches the thoughts and experiences of Winston Churchill, who was famed as a hero of Britain, but failed in conquering Turkey. Getting back to the matter of Chinese economic dominance in Singkawang and the Muslim businessmen's efforts 
to fight it, a certain anecdote from Churchill's life might be appropriate. Once, Churchill supposedly ordered one of his soldiers to catch a fish in a pond. Everytime the fish is almost caught, it would struggle and slipped free from the soldier's hands; this repeated ad infinitum until said soldier was exhausted, without managing to catch it. The soldier only managed to catch the fish by draining the pond, stranding the fish out of the water, ripe for a capture.

This anecdote might explain why the Muslim businessmen in Singkawang are until now mostly under the domination of Chinese businessmen, both economically and in other fields. Like the fish who was doomed by draining the pond's water, the Muslim businessmen, and Muslims in general, were doomed by their rivals "draining the waters" of their faith; distancing them from their guidance, Al-Qur'an and Sunnah, distancing them from masjids, distancing them from emulating Rasulullah, and distancing them from councils of wisdom. All this leads to the Muslims becoming fishes out of the water, struggling to maintain their existence. This is just like what Weber had predicted before.

\section{Chinese Economic Dominance}

The existence of Muslim businessmen amidst the Chinese economic superiority reminds one of the Paris Manuscripts (Coletti, 1975), which puts the politics of economics under scrutiny. Classical political economists, such as Smith and Ricardo had acknowledged the importance of the workers' economic contribution to the creation of wealth and values, but they haven't given the workers their appropriate place in politics or society. This is no different from what the Chinese experienced in the past, who despite having lived as farmers and traders from the era of Sambas Sultanate until the New Order, were "conditioned" to never stray from the field of economics, never given a chance to enjoy the political and social 
climate. This resulted in the Chinese becoming more and more skilled economically, but impoverished socially-absorbed. "Poor" socially here means that the Chinese tend to place social relations based on economic values considerations. They are generous in giving material and financial supports, but not in interacting in working processes. They are exclusive in choosing their residence, both by clustering with their fellow Chinese or by choosing to live in the business centers they built.

The Chinese economic dominance and recent political successes in Singkawang might be explained by using two different assumptions. First, it might be that political challenges are not so different from economic ones; thus, they are already familiar with them, and second, there might be some sort of oversaturation of Chinese new generation in the business world, thus pushing some to try their luck in the political world. No matter which of these two assumptions is the correct one, the result is the same; the Chinese existence in Singkawang is reinforced, both economically and politically.

When the "valve" of Chinese freedom was opened, during Gus Dur's government, the Chinese were liberated. Rather than being alienated, they are freed from proletarianism. Borrowing a Marxist socialist term (Marx-Engels, 1976), the Chinese might be said to be a clever group of workers. The Chinese growing dominance economically and politically in Singkawang seems to inspire the liberation of the proletariat from the pretenses of the bourgeoisie, or in other words, power in the Reformation era depends on the public needs. On the other hand, the Chinese seems ambivalent, like the capitalistic economics have sidelined their social potentials.

The government has created an era of economic growth laden with competition, enforcing an equality of opportunities, "without class". However, it seems that the capitalist system has created its own class system. 
The Chinese appear as capital owners and achievers of economic value, entrenching themselves as the elite, enhanced with their success in pairing economic and political dominance, as has been achieved in Singkawang. Looking back, there is nothing wrong in the current Chinese success in Singkawang, or the dismay felt by the Muslims about it. As Marx said in his axiom, all of history is the history of class struggle. Class struggle is the axis; the structures of class, work, and capital are according to Marx some of the central concepts in capitalism. Still about Marx's thoughts, history is not just a history of classes struggling — modern history is a "great war" between two fundamental classes, the bourgeoisie and the proletariat.

\section{Muslim Businessmen's Opposition}

Both the Chinese and the Muslim businessmen seems to be trying their hardest to reproduce themselves. This is the essential logic of the capital. The Muslim businessmen's inferiority to the Chinese spur them to construct all their knowledge and resources as a form of "opposition" to Chinese businessmen's dominance. The world of capitalism is laden with capital competitions, but a competition ignoring the self's essence as a religious man-as Weber and Churchill foresaw_would obviously gives an advantage to the Chinese businessmen.

For the Muslim businessmen in Singkawang, history has gradually aggrandized the Chinese, while giving them a valuable lesson on the process on becoming a winner in the competition-laden capitalist era. The elite Chinese businessmen are viewed to be able to couple the advantages of capitalism with elements of their culture and religiousity. The old Malay glory of religiousity and adherence to Islamic morals and culture should be reawakened for this era of modernity. Muslim businessmen can only become winners of the current capitalist system once they adhered closely to the Islamic teachings and religious values once again. 
While calling it a "revolution" might be a stretch, the internal logical developments of the Muslim businessmen has awakened their spirit to unite and build an Islamic business network, so that a sketch of their aim, an Islamic-"flavored" Singkawang can be feasibly fought for. This is important because economics is a fundamental determinant in order to create a legal, economic, and political superstructure, as well as building various forms of social awareness among the Muslims. For the Muslim businessmen, competing against the Chinese businessmen can be done through forging unity in business, building Muslim shopping, cuisine, or other business centers, and spreading awareness of the capitalist Chinese elitism as a central phenomenon in this modernity. What built the capitalist Chinese superiority in economics, particularly trade, that brings them into dominance in Singkawang might also be the thing that contributes to their gradual downfall.

These efforts to match capitalist Chinese economic dominance might feel difficult, but the Muslim businessmen seems to be certain and hopeful, awakening an Islamic economic spirit as a sign of significant opposition. Just as two identical dishes might have different prices depending on where it is served, the Muslim community can judge the products served by the Muslim businessmen, boiling the Islamic values into a measurable economic value, united, yet appreciating the differences that should characterize Muslim daily lives. Labor should still be treated as humans, rather than mere cogs in the machine. The typical capitalist system that tends to become "hell" for the workers should be stopped and replaced with a system treating them as "students" of a "school" of work. The workers' struggle to earn a decent living should not be treated as objects for the capitalist "vampire" to devour, but as subjects in developing a pure Sharia-based Muslim business. The mostly Chinese-dominated capitalism in Singkawang must be opposed, especially if it is found out 
that there are elements of Muslim exploitation in it.

The Chinese ethnic dominance economically, and the attempts of opposition being built by Muslim businessmen are fundamental facts of the new civilization in Singkawang. Factually, referring to Marx's thoughts, class struggle never ends. Capital, and by extension power and dominance, are still being fought over. The problem is the Muslim businessmen must be able to "Islamify" the Muslims of Singkawang, to earn their support and establish an Islamic capitalism. Thus, daily life, world system, uniqueness and complexity of the business competitions must rely on Muslim social and cultural systems, rather than mere reductions as business world and usage of products.

The industrialism built by Muslim businessmen in Singkawang, to respond against the desire for Islam's glory in the city might be opposed by many; reawakening the Muslim's imagination that Muslim economics is better than pure capitalism. Thus far, the need for pleasure has been twisted into unlimited consumption of industrial products, becoming a critical differentiator between daily existence and reflection of Islamic culture, especially considering the capitalism practiced by the Chinese tend to reduce social relations as capitalistic value exchange relations. Talking about social capital reminds one of the thoughts of Robert M.Z. Lawang (Lawang, 2000). Social capital refers to the powers improving the potential of economic growth in a society by creating and maintaining social relations, as well as social organization patterns. This statement, cited from Turner's views as summarized by Dasgupta, is viewed as one of the definitions of social capital, which placed social capital as an independent variable. Considering social capital is the reason for individual and collective acts that allow for the achievement of usability and results.

Actually, Muslim businessmen should be proud of the local social wisdom, which is still maintained until now. Thus, there are some who 
viewed these local wisdoms as social capital. The social acts originating from those wisdom would not disturb the balance, they are even often very effective in solving social problems, particularly social conflicts, by creating solutions without spreading the conflicts everytime a clash of economic and political interests happen; for example the image of gotongroyong which, as a local wisdom, is considered a social capital. Economic experts in organization study states that efficiency shown by social capital contribution in an investment is actually due to the decrease of monitoring and evaluation costs, because of trust, commitment, loyalty, and hierarchy, manifested in gotong-royong. For the Chinese, who are known as experts in building their business, it might not be because of their high social capital, but due to their expertise in playing the business strategy based on profit calculations.

At the very least there are several patterns of established work patterns related to gotong-royong to improve the existence of Muslim businessmen. This is in order to measure the efficiency of social capital, despite it being a non-economic effort, in an effort to solve social problems with local wisdom, that can only be done by verbalization accompanied by conviction, that in a short time and relatively cheap cost. As the principle of synergy states, that an activity would succeed if all capital (human, physical, and social), available amon the society can be used as optimally as possible. This principle is not only functional in achieving goals, but also to maintain activities and projections of the work itself.

Based on the perspective of capitalism, social capital is not everything. It needs to be underlined, because the achievement of an economic goal effectively and efficiently in order to solve a problem will be achieved if all available capital in society is used in synergy, because capital synergy in development is also connected with cooperation or interactive relations between components of governance, whether horizontally or 
vertically. The Muslim businessmen are hoped to have the ability to push the government to facilitate the developmet program about provision of business capital for Muslim businessmen starting out, whether through physical capital aids and social capital in the form of institutions or norms and values that push or facilitate the closeness of relations between fellow Muslim businessmen.

This is what makes social capital a basic capital that needs to be explored, so that it becomes a real power for achieving a goal. For example, the problem of poverty that often becomes a social burden or the problem of unemployment that affected the Muslim community, which continues to attract attention are actually not unrelated to the Muslim businessmen's powerlessness in humanizing them, without ognoring the roles of government institutions or the rest of the business world community as the main components of the governance, or also something "deliberately" created by certain people to manipulate the government, in order to achieve clandestine profits due to privatization which is not open enough about its management system.

The presence of Muslim businessmen in Singkawang should be accompanied with their ability in preparing the society-particularly the rural people around Singkawangkhususnya masyarakat pedesaan di sekitar Kota Singkawang — of their usage, due to the essential goals, just like how the Chinese businessmen supposedly prosper due to starting from seizing control of the village's potential, until they become a part of the creation of commercial farmers, industry and rural production, as well as improving their life condition. The same thing also applies to the mechanization of agriculture, as one of the efforts in boosting the productivity of agricultural work, improving its quality and results, and minimizing production costs. It seems that the Muslim businessmen hve to think hard about this mechanization, so that the potential to complete a pattern of dynamic 
advanced agriculture, a real part in supporting the soon-to-be-obtained big project.

It must be realized that the development of business efforts into a competent economic fighter is not as easy as turning over a hand; modernization of thought obviously must continue to be developed as the competition-laden world of capitalism rages on, which for now cannot be denied to be under the control of the Chinese, especially in Singkawang. The process of modernization in building the economic business network does not automatically lead to a frontal clash against the already established Chinese businessmen. Thus, it is not wrong to do integral adjustments, which does not only include technical economic aspects, between Muslim and Chinese businessmen in Singkawang through new value systems, solving socio-cultural problems faced economically-so that a multicultural economic network is built in Singkawang.

\section{Conclusion}

There is a tendency among the elites in the current era of modernization to reduce social values into economic values. Workers "sink" into idolization of objects, slipping into worship of the transient world. Struggle is still the main problem for the two classes, the Muslim businessmen and their Chinese counterparts, occupying the elite class of Singkawang. Capitalism itself, as part of the work and capital of Muslim and Chinese businessmen, as a system that is no different in their method exploiting all and every people. The question is: is there a desire among Muslim businessmen to create an Islamic-characterized Singkawang, as now Singkawang is tightly associated with Chinese civilization, which has dominated it economically and politically. Thus, it is only fitting to label the Chinese in Singkawang as the "elite". 
This desire for an Islamic Singkawang is still intact. The rise of efforts restoring the Islamic civilization in Singkawang seems to have been started by Muslim businessmen. The rise of Muslim businessmen with the spirit of Islam, in trade, hotels, restaurants, and other small and intermediate businesses, even if somewhat premature, is still an opposition against the Chinese elite, an effort to realize the project of associating Singkawang with Islamic civilization. The Muslim businessmen now have concepted new values doubling new interpretations for the birth of an Islamic business culture in Singkawang. The building of projection to realize a Muslim shopping, cuisine, and various other production and consumption activity centers, is a rational and ideal thing.

The efforts of Muslim businessmen are not a matter of clash between materialism and idealism, or dichotomy or arena for a clash between Muslim businessmen and Chinese elite, but as an effort through subjective actions to bring situational conditions or "reality" to the ideal condition. The Muslim societal life must be normative, working not to be a capitalist worshipper or a coercive ruler, but to work and rule to solidify the religious spirit. The existence of Muslim businessmen that includes work and capital should be expressed as "orientation towards", rather than "determined by"; as Weber said, religion should be the spirit guiding to happiness in life and obtaining the blessings of God, even creating capitalism, not in order to distance one from religiousity, as capitalism has distanced its worshippers from their ideal character as religious people. These efforts of Muslim businessmen in Singkawang is also in order to respond against their powerlessness, or the gradual destruction of the Muslim existence in Singkawang — as what can be learned from an anecdote of Churchill. 


\section{References}

Beilharz, Peter. 2003. Teori-teori Sosial. Observasi Kritis terhadap Para Filosof Terkemuka. Yogyakarta: Pustaka Pelajar.

Marx, Karl. 1844. Paris Manuscripts. In L. Coletti (ed). 1975. Marx Early Writings. Harmondsworth, Penguin.

Marx, Karl. Engels, F. 1845. The German Ideology in Marx-Engels. 1976. Collected Works. Volume 5. London: Lawrence and Wishart.

Miles B and M, Huberman. 1992. Analisis Data Kualitatif. Bandung: Bina Rosda Karya.

Peraturan Pemerintah Republik Indonesia Nomor 10 Tahun 1959 tentang Larangan Orang non Pribumi, WNA untuk Tidak Bermukim dan Berwirausaha di Desa-desa, atau Wilayah/daerah Pedalaman.

Robert M.Z. Lawang. 2000. Kapital Sosial dalam Perspektif Sosiologik Suatu Pengantar. Jakarta: Fisip UI Press.

Weber, M. 1904. The Protestant Ethic and Spirit of Capitalism. New York: Scribners. 


\section{Shirkah Author Guidelines}

Shirkah currently offers two routes to submit manuscripts. We highly recommend to submit the articles which are made using OJS (Open Journal System). Feel free register as author soon through visiting http:// shirkah.or.id/index.php/home/user/register. The authors may directly send their manuscripts, along with their resume, to shirkahiainsurakarta@ gmail.com. Please prepare your manuscripts, using following guidelines:

1. Manuscript must be written in English. Submitted articles should not have been published or be under review for publication with another journal.

2. Manuscript's length is about $15-20$ pages, typed in one-half spaced on A4-paper size.

3. Manuscript must include an $150-200$ word abstract and keywords.

4. Manuscript must be arranged as follows: Title, Name of Author, E-mail address, Abstract, Keywords, Introduction (including method if any), Discussion, Conclusion, References.

5. Manuscript's titles not more than ten words.

6. Manuscript must be submitted in Microsoft Word or RTF.

7. Arabic words should be transliterated according to the style of International Journal of Middle Eastern Studies.

8. Manuscript references are preferably derived from the up-to-date references.

9. The author's resume should be submitted separately, consisting of at least full name, institutional address, phone number, areas of studies, and recent publications (if any).

10. Shirkab use APA Style 6th edition (2010) as reference format writing. We suggest the use of a reference manager software such as Mendeley, Zotero, and Endnote at templating the citation style. APA Style to be used is as follows: 


\section{Book with single author}

Swann, G. M. Peter. (2014). The Economics of Innovation an Introduction. Cheltenhum \& Northampton: Edward Elgar.

in-text citation: (Swann, 2014)

\section{Articles in reference books}

Alatas, S. F. (2006). Islam and the Science of Economics in Abu Rabi', I.M. The Blackwell Companion to Contemporary Islamic Thought. USA: Willey-Blackwell (pp. 587-606).

in text citation: (Alatas, 2006)

\section{E-Book}

Hackett, Rosalind (2007). "Religous Dimentions of War and Peace: Introduction.” Dalam Gerrie ter Haar dan Yoshio Tsuruoka (Ed.), Religion and Society: An Agenda for the 21st Century (h. 3-6). Retrieved from http:// brill.nl.

in text citation: (Hackett, 2006)

\section{Master's thesis, from a commercial database}

McNieI, D. S. (2006). Meaning through narrative: A personal narrative discussing growing up with an alcoholic mother (Master's thesis). Available from ProQuest Dissertations and Theses database. (UMI No. 1434728)

in text citation: (Mc Niel, 2006)

\section{Doctoral dissertation, from an institutional database}

Adams, R. J. (1973). Building a foundation for evaluation of instruction in higher education and continuing education (Doctoral dissertation). Retrieved from http://www.ohiolink.edu/etd/

in text citation: (Adams, 1973) 


\section{Doctoral dissertation, from the web}

Bruckman, A. (1997). MOOSE Crossing: Construction, community, and learning in a networked virtual world for kids (Doctoral dissertation, Massachusetts Institute of Technology). Retrieved from http:/www-static. cc.gatech.edu/--asb/thesis/

in text citation: (Bruckman, 1997)

\section{Journal article with No DOI}

Bourkhis, K., and Nabi, M. S. (2013). Islamic and conventional banks' soundness during the 2007-2008 financial crisis. Journal Metrics, 22(2), 68-77.

in-text citation: (Bourkhis \& Nabi, 2013).

\section{Journal article with DOI}

Ichwan, M. (2012). The Local Politics Of Orthodoxy: The Majelis Ulama Indonesia in the Post-New Order Banten. Journal Of Indonesian Islam, 6(1), 166-194. doi:http://dx.doi.org/10.15642/JIIS.2012.6.1.166-194

In text citation : (Ichwan, 2012)

\section{Abstract as citation}

Hasan, N. (2012). Islamist Party, Electoral Politics And Da'wah Mobilization Among Youth : The Prosperous Justice Party (PKS) in Indonesia. Journal of Indonesian Islam, 6(1), 17-47. Abstract from http:// jiis.uinsby.ac.id/index.php/jiis/article/view/97

in text citation : (Hasan, 2012)

\section{Mass media article}

Sahal, Akhmad (2014, March 2). Kiai Sahal dan Realisme Fikih.Tempo Magazine, p. 120.

in text citation : (Sahal, 2014) 


\section{Research report}

Fisher, B. S., Cullen, F. T., \& Turner, M. G. (2000). The Sexual Victimization of College Women. Research Report.

in text citation : (Fisher, Cullen, Turner, 2000)

\section{Monograph}

Routray, Bibhu Prasad (2013), National Security Decision-Making in India (RSIS Monograph No. 27). Singapura: Rajaratnam School of International Studies.

in text citation : (Routray, 2013)

\section{Proceeding article}

Sudibyakto, Hizbaron, D.R., \& Jati, R (Ed.) (2009), Proceeding International Seminar Disaster Theory, Research and Policy. International seminar held by Sekolah Pascasarjana, Universitas Gajahmada, Yogyakarta, 8-9 Desember 2009.

in text citation : (sudibyakto and Jati, 2009)

\section{Paper conference/seminar/symposium}

Janutama, Herman Sinung (2011). "Kraton dan Hubungan Antar Agama." Paper presented in Seminar Kraton dan Panatagama held by Center for the Study of Islam and Social Transformation (CISForm), Yogyakarta, 17 November.

in text citation :(Janutama, 2011)

\section{Online article in web}

Shiva, (2006, February). Bioethics: A Third World Issue. Native-web. Diperoleh dari http://www.nativeweb.org/ pages/legal/shiva.html

in text citation : (Shiva, 2006) 


\section{Online research report}

Kessy, S. S. A., \& Urio, F M. (2006). The contribution of microfinance institutions to poverty reduction in Tanzania (Research Report No. 06.3). Retrieved from Research on Poverty Alleviation website: http://www. repoa.or.tz /documents_storage/Publications/Reports/06.3_Kessy_and_ Urio.pcif

in text citation : (kessy and urion, 2006)

\section{Holy book}

Qur an, $2(25)$

In text citation : (Q. al-Baqarah 2:25).

\section{Encyclopaedia}

Graycar, Adam (1992). Social Welfare Policy. Dalam Mary Hawkesworth dan Maurice Kogan (Ed.), Encyclopedia of Government and Politics (Vol. 1). London: Routledge.

in text citation : (Graycar, 1992)

\section{Interview}

Sultan Hamengkubuwono X (interview, 2011, April 19)

in text citation: (Hamengkubuwono, 2011)

\section{Documentary film}

Steijlen, Fridus (2008). A Day in the Life of Indonesia [documentary film, 58 minutes]. Leiden: KITLV Press.

in text citation : (Steijlen, 2008) 
Vol. 4 No. 2, May - August 2019 